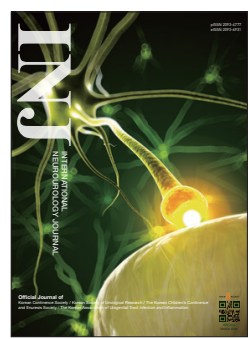

\title{
Ketanserin and Naftopidil Enhance the Potentiating Effect of Alpha-Methyl-Serotonin on the Neurally-Induced Contraction of Human Isolated Urinary Bladder Muscle Strips
}

\author{
Tsuyoshi Hattori ${ }^{1}$, Philippe Lluel², Céline Rouget ${ }^{2}$, Moèz Rekik² ${ }^{2}$ Mitsuharu Yoshiyama ${ }^{3}$ \\ ${ }^{1}$ Department of Medical Affairs, Asahi Kasei Pharma Corporation, Tokyo, Japan \\ ${ }^{2}$ Department of Pharmacology, UROsphere SAS, Toulouse, France \\ ${ }^{3}$ Department of Urology, University of Yamanashi Graduate School of Medical Science, Chuo, Yamanashi, Japan
}

Purpose: The aim of this study was to assess the potential involvement of a specific subtype of 5-hydroxytryptamine (5-HT), $5 \mathrm{HT}_{2}$ receptors in neurally-induced contractions of the human detrusor.

Methods: Contractile responses to electrical field stimulation (EFS) were examined in human isolated urinary bladder muscle strips. The potentiation of EFS-induced detrusor contraction was examined by adding cumulative concentrations of a 5-HT and $5-\mathrm{HT}_{2}$ receptor agonist, $\alpha$-methyl-serotonin $(\alpha-\mathrm{Me}-5-\mathrm{HT})(1 \mathrm{nM}-100 \mu \mathrm{M})$ in the presence or absence of a $5-\mathrm{HT}_{2}$ antagonist, ketanserin $\left(5-\mathrm{HT}_{2 \mathrm{~A}}>5-\mathrm{HT}_{2 \mathrm{C}}\right)$ or naftopidil $\left(5-\mathrm{HT}_{2 \mathrm{~B}}>5-\mathrm{HT}_{2 \mathrm{~A}}\right)(0.3-3 \mu \mathrm{M})$.

Results: 5-HT and $\alpha-M e-5-H T$ potentiated EFS-induced contraction with a maximal effect $\left(\mathrm{E}_{\max }\right)$ of $37.6 \%$ and $38.6 \%$, respectively, and with $\mathrm{pEC}_{50}$ (negative logarithm of the concentration required for a half-maximal response to an agonist) values of 8.3 and 6.8, respectively. Neither ketanserin nor naftopidil at any concentration produced a rightward displacement of the $\alpha-\mathrm{Me}-5-\mathrm{HT}$ concentration response curve. Instead, the $\mathrm{E}_{\max }$ of $\alpha-\mathrm{Me}-5-\mathrm{HT}$ increased in the presence of ketanserin at $0.3-1 \mu \mathrm{M}$ and in the presence of naftopidil at $1 \mu \mathrm{M}$ to $51 \%$ and $56 \%$, respectively, while the $\mathrm{E}_{\max }$ in the presence of vehicle alone was $36 \%$. The highest concentration $(3 \mu \mathrm{M})$ of either drug, however, fully reversed the enhancement.

Conclusions: The potentiating effect of $\alpha-\mathrm{Me}-5-\mathrm{HT}$ on neurally-induced contraction of human urinary bladder muscle strips was not found to be mediated via any $5-\mathrm{HT}_{2}$ receptor subtypes. The underlying mechanism for the enhancement of the $\alpha$-Me5-HT potentiating effect on detrusor contractility by ketanserin and naftopidil remains unknown; however, our results suggest that these drugs may be useful for treating contractile dysfunction of the detrusor, as manifested in conditions such as underactive bladder.

Keywords: Serotonin Receptors; Alpha-1 Adrenergic Receptors; Urinary Bladder Neck Obstruction; Prostatism; Underactive Bladder

- Research Ethics: The present study was conducted in accordance with the European Council Directive 2006/17/CE regarding technical requirements for the donation, procurement, and testing of human tissues and cells.

- Conflict of Interest: Dr. Hattori is an employee of Asahi Kasei Pharma Corporation. Dr. Rouget, Dr. Rekik, and Dr. Lluel studied under a grant from Asahi Kasei Pharma Corporation. Dr. Yoshiyama reports personal fees from Asahi Kasei Pharma Corporation and UROsphere SAS.

\footnotetext{
- HIGHLIGHTS

- The potentiation by a-Me-5-HT of neurally-evoked contraction of human detrusor strips was not mediated via $5-\mathrm{HT}_{2}$ receptor subtypes, and was enhanced by ketanserin or naftopidil.

- Ketanserin and naftopidil may be useful for treating contractile dysfunction of the detrusor such as underactive bladder.
}

Corresponding author: Tsuyoshi Hattori (iD http://orcid.org/0000-0001-6425-3945 Department of Medical Affairs, Asahi Kasei Pharma Corporation, 1-105 Kanda Jinbocho, Chiyoda-ku, Tokyo 101-8101, Japan

E-mail: hattori.tg@om.asahi-kasei.co.jp / Tel: +81-3-3296-3718 /

Fax: +81-3-3296-3614

Submitted: October 31, 2016 / Accepted after revision: February 1, 2017 


\section{INTRODUCTION}

Serotonin (5-hydroxytryptamine, 5-HT) is a monoamine neurotransmitter that acts via membrane receptors in the central nervous system, the peripheral nervous system, and nonneuronal cells in blood platelets, the gastrointestinal tract, the endocrine system, the sensory system, and the cardiovascular system [1]. To date, 7 families of 5 - $\mathrm{HT}$ receptors $\left(5-\mathrm{HT}_{1}\right.$ through $5-\mathrm{HT}_{7}$ ) have been identified based on sequence homologies and effector pathways [1]. 5-HT receptors, with the exception of the 5- $\mathrm{HT}_{3}$ class, are G-protein-coupled receptors, and are classified into 13 distinct subtypes: $5-\mathrm{HT}_{1 \mathrm{~A}}, 5-\mathrm{HT}_{1 \mathrm{~B}}, 5-\mathrm{HT}_{1 \mathrm{D}}$, 5-ht ${ }_{1 \mathrm{e}}, 5-\mathrm{HT}_{1 \mathrm{~F}}, 5-\mathrm{HT}_{2 \mathrm{~A}}, 5-\mathrm{HT}_{2 \mathrm{~B}}, 5-\mathrm{HT}_{2 \mathrm{C}}, 5-\mathrm{HT}_{4}, 5-\mathrm{ht}_{5 \mathrm{a}}, 5-\mathrm{ht}_{5 \mathrm{~b}}$, $5-\mathrm{HT}_{6}$, and $5-\mathrm{HT}_{7}$ [2]. 5- $\mathrm{HT}_{3}$ receptors belong to the ligandgated ion channel receptor superfamily, and are divided into 5 subcategories: 5- $\mathrm{HT}_{3 \mathrm{~A}}, 5-\mathrm{HT}_{3 \mathrm{~B}}, 5-\mathrm{HT}_{3 \mathrm{C}}, 5-\mathrm{HT}_{3 \mathrm{D}}$, and 5- $\mathrm{HT}_{3 \mathrm{E}}$ [2]. 5-HT receptors have been implicated in the central and peripheral regulation of lower urinary tract function $[3,4]$; however, the physiological role of each 5-HT subtype has been difficult to investigate because of the lack of receptor subtype-specific agonists and antagonists.

Peripherally, 5-HT has been implicated in the modulation of detrusor contraction in mammals, including humans [3]. In resting preparations of human isolated bladder strips, 5-HT-induced contraction was found to be directly and partly mediated by the $5-\mathrm{HT}_{2}$ receptor subtype located on the effector cells because the effect was inhibited by ketanserin (a $5-\mathrm{HT}_{2}$ antagonist) but not by tetrodotoxin [5]. Meanwhile, in the electrical field stimulation (EFS)-evoked contraction of human urinary bladder strips, 5-HT-potentiation of the detrusor contraction has been shown to be mediated via 5-HT receptor subtypes, with the exception of $5-\mathrm{HT}_{1}, 5-\mathrm{HT}_{2}$, and $5-\mathrm{HT}_{3}$, because methysergide (a 5- $\mathrm{HT}_{1} / 5-\mathrm{HT}_{2}$ antagonist), ketanserin, and ondansetron (a $5-\mathrm{HT}_{3}$ antagonist) had no effect on the potentiation [6]. This indirect potentiation of detrusor contraction is thought to be mediated by facilitating acetylcholine $(\mathrm{ACh})$ release from parasympathetic terminals via $5-\mathrm{HT}_{4}$ and $5-\mathrm{HT}_{7}$ receptors $[7,8]$. Thus, in the human bladder, in addition to major patterns of mediation via muscarinic receptors, detrusor contractility is modulated by complex mechanisms, partly involving $5 \mathrm{HT}$ receptor subtypes.

A recent study using real-time polymerase chain reaction (PCR) and immunohistochemical techniques showed that the expression of $5-\mathrm{HT}_{2 \mathrm{~B}}$ receptor mRNA was markedly greater than that of other 5-HT subtypes in the human detrusor and that the receptors were distributed throughout the muscle layer [9]. These results suggest the possibility that this receptor subtype plays an important role in the modulation of urinary bladder function. In addition, 5- $\mathrm{HT}_{2 \mathrm{~A}}$ mRNA was also expressed in the human detrusor with a low expression level, corresponding to one-seventh of that of 5- $\mathrm{HT}_{2 \mathrm{~B}} \mathrm{mRNA}$ [9].

The aim of this study was to determine the pharmacological significance of specific $5-\mathrm{HT}_{2}$ subtypes (i.e., $5-\mathrm{HT}_{2 \mathrm{~A}}, 5 \mathrm{HT}_{2 \mathrm{~B}}$, and $5-\mathrm{HT}_{2 \mathrm{C}}$ ) in the potentiation of EFS-induced contraction of human isolated urinary bladder strips. The agonist used was a-methyl-5-hydroxytryptamine (a-Me-5-HT), which shows selectivity for $5-\mathrm{HT}_{2 \mathrm{~B}}, 5-\mathrm{HT}_{2 \mathrm{C}}$, and $5-\mathrm{HT}_{2 \mathrm{~A}}$ in order, with pKi values of 8.4, 7.3, and 6.1, respectively [10]. To block 5- $\mathrm{HT}_{2}$ receptor transmission, ketanserin and naftopidil were used to determine the receptor subtype predominantly involved in the potentiation of detrusor contraction, as these drugs have a fairly high binding affinity for $5-\mathrm{HT}_{2 \mathrm{~A}} / 2 \mathrm{C}$ receptors $\left(5-\mathrm{HT}_{2 \mathrm{~A}}>5-\mathrm{HT}_{2 \mathrm{C}}\right)$ and $5-\mathrm{HT}_{2 \mathrm{~A}} \mathrm{2}_{2 \mathrm{~B}}$ receptors $\left(5-\mathrm{HT}_{2 \mathrm{~B}}>5-\mathrm{HT}_{2 \mathrm{~A}}\right)$, respectively $[11,12]$. These drugs, which have been shown to ameliorate micturition disturbances in human patients, were selected to explore their possible further clinical benefits as well as to elucidate the basic scientific questions addressed in this study $[13,14]$.

\section{MATERIALS AND METHODS}

\section{Isolated Human Urinary Bladder}

The present study was conducted in accordance with the European Council Directive 2006/17/CE regarding technical requirements for the donation, procurement, and testing of human tissues and cells.

Human tissues were obtained from 6 male patients with a mean age of $63 \pm 3$ years (range, $55-74$ years). All patients (negative for human immunodeficiency virus 1-2, human T-lymphotropic virus $1-2$, and hepatitis $B$ and $C$ ) had undergone a cystoprostatectomy for bladder cancer. The tissues were donated after obtaining the patients' written informed consent. Clinical information about the patients is presented in Table 1.

\section{Experimental Protocol}

Each sample of bladder tissue was inspected by direct visual assessment to confirm that it did not include any parts of the malignancy. The detrusor specimen was cleaned of fat and connective tissues, the urothelium removed, and remaining detrusor muscle cut into several strips (length, 9-10 mm; width, 3-4 $\mathrm{mm}$ ), which were immersed in 5-mL organ baths (EMKA 
Table 1. Patients' clinical backgrounds before cystoprostatectomy

\begin{tabular}{|c|c|c|c|c|c|c|}
\hline Variable & $\# 1$ & $\# 2$ & $\# 3$ & $\# 4$ & $\# 5$ & $\# 6$ \\
\hline Age (yr) & 60 & 67 & 55 & 55 & 74 & 68 \\
\hline Anticancer therapy & - & - & Chemotherapy $y^{a)}$ & - & $\mathrm{BCG}^{\mathrm{b})}$ & $\mathrm{BCG}^{\mathrm{c}}$ \\
\hline Date of surgery & Aug 27, 2015 & Sep 8,2015 & Sep 28, 2015 & Oct 6, 2015 & Oct 12, 2015 & Oct 22,2015 \\
\hline Other treatment & Antithrombotic & $\begin{array}{l}\text { Antibiotic, antimuscarinic, } \\
\alpha_{1} \text {-adrenoceptor blocker }\end{array}$ & Folic acid, analgesic & - & - & - \\
\hline
\end{tabular}

One patient (\#3) received intravenous neoadjuvant chemotherapy: ${ }^{\mathrm{a})} 3$ cycles of methotrexate, vinblastine, doxorubicin and cisplatin, until Jul $30,2015$. Two patients (\#5 and \#6) received Bacillus Calmette-Guérin (BCG) therapy: ${ }^{\text {b) }} 6$ cycles, 1 instillation per week (Sep 17, 2014 to Oct 29, 2014) followed by another 3 cycles, 1 instillation per week (Jan 29, 2015 to Feb 12, 2015); and ${ }^{\text {c) }} 6$ cycles, 1 instillation per week (May 1, 2015 to Jun 12, 2015 ).

Technologies, Paris, France) containing Krebs buffer (composition in $\mathrm{mM}: \mathrm{NaCl}, 114 ; \mathrm{KCl}, 4.7 ; \mathrm{CaCl}_{2}, 2.5 ; \mathrm{MgSO}_{4}, 1.2 ; \mathrm{KH}_{2} \mathrm{PO}_{4}$, 1.2; $\mathrm{NaHCO}_{3}, 25$; and glucose, 11.7; $\mathrm{pH} 7.4$, incubated under $95 \% \mathrm{O}_{2}$ and $5 \% \mathrm{CO}_{2}$ at $\left.37^{\circ} \mathrm{C}\right)$ and mounted under $1 \mathrm{~g}(10 \mathrm{mN})$. The Krebs buffer also contained prazosin $(1 \mu \mathrm{M})$ in order to block $\alpha_{1}$-adrenoceptors. Contractile responses were measured using isometric tension transducers (it-1, EMKA Technologies), and were recorded using Chart software version 7.3.7 and the PowerLabs 8/30 data acquisition system (AD Instruments Pty Ltd., Castle Hill, Australia), running on a personal computer. EFS was performed through platinum electrodes connected to constant current asynchronous stimulators (Model stm-b01, EMKA Technologies). The tissue samples were allowed to equilibrate for at least 60 minutes, during which time contraction with $80 \mathrm{mM} \mathrm{KCl}$ was performed on each strip. After a 30-minute washout period, tissues were stimulated by EFS for approximately 30-45 minutes, until a stable plateau of contractile responses was obtained, using the following parameters: constant current, $800 \mathrm{~mA}$; frequency, $10 \mathrm{~Hz}$; train duration, 0.1 ms; 5 seconds of train pulses, every 62.5 seconds.

Tissues were stimulated by EFS for 2 serial experiments. In the first experiment, a cumulative concentration-response curve (CRC) for 5-HT or $\alpha-\mathrm{Me}-5-\mathrm{HT}$ was constructed, in the range of $1 \mathrm{nM}$ to $100 \mu \mathrm{M}$ (in half-log increments). The corresponding volume of vehicle was added to strips in the control group. In the second experiment, the cumulative CRC for a-Me-5-HT, in the range of $10 \mathrm{nM}$ to $100 \mu \mathrm{M}$ (in half-log increments) was constructed in the presence of ketanserin $(0.3,1$, and $3 \mu \mathrm{M})$, naftopidil $(0.3,1$, and $3 \mu \mathrm{M})$ or their common vehicle, diluted dimethyl sulfoxide (DMSO; $0.4 \%$ in distilled water) by incubation for 30 minutes before the first addition of a-Me5-HT. At the end of both experiments, the nature of the neurogenic contractions was confirmed in at least 2 strips per patient using tetrodotoxin $(1 \mu \mathrm{M})$.

\section{Drugs}

5-HT hydrochloride, a-Me-5-HT maleate, ketanserin tartrate, and tetrodotoxin were purchased from Tocris (Bristol, UK). Naftopidil was synthesized at the Asahi Kasei Pharma Corporation (Tokyo, Japan). Prazosin hydrochloride was obtained from Sigma-Aldrich (St-Quentin-Fallavier, France). Stock solutions of naftopidil and ketanserin were prepared on each day of experimentation at a concentration of $0.01 \mathrm{M}$ in DMSO. Further dilution was carried out using a mixture of distilled water and DMSO.

\section{Statistical analyses}

Values are expressed as mean \pm standard error of the mean. Responses to agonist concentrations are expressed as the difference between the basal value of contraction induced by EFS (calculated at the end of the stabilization period) and the maximal amplitude of contraction recorded following the addition of each agonist concentration into the organ bath. This delta value (in grams) was normalized against the amplitude of contractions induced by $80 \mathrm{mM} \mathrm{KCl} \mathrm{(in} \mathrm{grams),} \mathrm{and} \mathrm{expressed} \mathrm{in}$ terms of percentage of the overall contraction induced by $\mathrm{KCl}$. Fitting and statistical analysis of the results were performed using GraphPad Prism version 6.0 (GraphPad Software Inc., San Diego, CA, USA). The following parameters were determined: the maximal effect induced by the agonist $\left(E_{\max }\right)$ and the negative logarithm of the concentration required for a half-maximal response to an agonist $\left(\mathrm{pEC}_{50}\right)$. The effects of $\mathrm{KCl}$ and the amplitude of basal contraction in response to EFS were compared using 1-way analysis of variance. Each CRC for $\alpha-M e-5-H T$ in the presence of ketanserin and naftopidil was compared to the corresponding vehicle CRC using the F-test. A global comparison of the curves was first established. When statistical significance was detected, successive comparisons of $\mathrm{E}_{\max }$ and $\mathrm{pEC}_{50}$ values were performed in order to determine which parameter 
was different. Differences were considered to be statistically significant when the null hypothesis could be rejected at a risk ( $\alpha$ ) of $<0.05$.

\section{RESULTS}

\section{Potentiation by 5-HT and $\alpha-M e-5-H T$ in EFS-Induced Detrusor Contraction}

The tonic and the phasic contractions induced by $80 \mathrm{mM} \mathrm{KCl}$ and EFS, respectively, among the 5-HT, $\alpha-\mathrm{Me}-5-\mathrm{HT}$, and vehicle groups were shown to have no statistically significant differences, and were homogeneous across the groups.

Both agonists (5-HT and $\alpha-\mathrm{Me}-5-\mathrm{HT})$ potentiated EFS-induced contractions to a similar extent, with a maximal effect reaching $37.6 \% \pm 4.2 \%(\mathrm{n}=9$ strips) and $38.6 \% \pm 6.6 \%(\mathrm{n}=6$ strips), while their $\mathrm{pEC}_{50}$ values were different $(8.3 \pm 0.2$ and

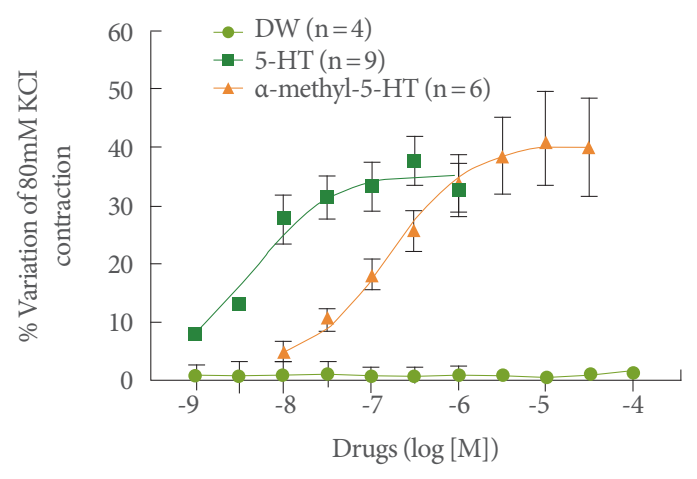

Fig. 1. Effects of 5-hydroxytryptamine (5-HT), a-methyl-5-HT, or the vehicle (distilled water, DW) on electrical field stimulation-induced contractions of human urinary bladder strips. Contractile responses are expressed as the percentage of the variation of the contraction observed with $80 \mathrm{mM} \mathrm{KCl}$. Data are presented as mean \pm standard error of the mean. The experiments were performed using $n=4-9$ strips per group from 2 patients.
$6.8 \pm 0.2$, respectively) (Fig. 1 ). The vehicle had no effect on EFS-evoked contractions ( $n=4$ strips). At the end of the experiments, $1 \mu \mathrm{M}$ tetrodotoxin almost eliminated the EFS-induced contractions of human isolated urinary bladder ( $82 \%-98 \%$, $\mathrm{n}=4$ strips), confirming their neurogenic origin. After this set of experiments, $\alpha$-Me-5-HT was used as a potentiating substance in the next experiment, as it demonstrated an acceptable potentiating response and has been described as having greater selectivity for the $5-\mathrm{HT}_{2}$ receptor.

\section{Effect of Ketanserin or Naftopidil on Potentiation by a-Me- 5-HT in EFS-Induced Detrusor Contraction}

In a series of experiments, the bladders of 2 patients were exposed to Bacillus Calmette-Guérin (BCG) therapy before cystectomy (Table 1). A comparison of bladders that did and did not undergo BCG therapy in the CRC for a-Me-5-HT of EFSinduced detrusor contraction was conducted, showing that this treatment did not change the CRC to a significant extent $(\mathrm{P}=0.066)$.

No antagonistic effects on the CRC for $\alpha-M e-5-H T$ were found to result from ketanserin or naftopidil treatment at any concentration (Table 2). However, the maximal effect of $\alpha-\mathrm{Me}-$ 5 -HT was significantly higher in the presence of ketanserin $(0.3$ and $1 \mu \mathrm{M}$ ), with a mean maximal effect of $36.4 \% \pm 2.2 \%$ in the vehicle group, and $50.9 \% \pm 2.8 \%$ and $51.2 \% \pm 3.0 \%$ in the 0.3 and $1 \mu \mathrm{M}$ ketanserin groups $(\mathrm{P}<0.0001$ for each), respectively, and in the presence of naftopidil $(1 \mu \mathrm{M})$ with a mean maximal effect of $55.7 \% \pm 4.1 \%(\mathrm{P}<0.0001)$ (Table 2 and Figs. 2, 3). A slight additional potentiating effect was observed with $0.3 \mu \mathrm{M}$ of naftopidil, but this effect did not reach significance. At the highest concentration of $3 \mu \mathrm{M}$, neither ketanserin nor naftopidil had an inhibitory effect on the potentiating activity of $\alpha-\mathrm{Me}-5-\mathrm{HT}$. $\mathrm{pEC}_{50}$ values were not significantly modified in the presence of either drug.

Table 2. Concentration-response curve parameters of ketanserin and naftopidil

\begin{tabular}{|c|c|c|c|c|c|c|c|}
\hline \multirow{3}{*}{ Variable } & \multicolumn{7}{|c|}{ Group } \\
\hline & \multirow{2}{*}{$\operatorname{DMSO}(\mathrm{n}=6)$} & \multicolumn{3}{|c|}{ Ketanserin $(n=6)$} & \multicolumn{3}{|c|}{ Naftopidil $(n=6)$} \\
\hline & & $0.3 \mu \mathrm{M}$ & $1 \mu \mathrm{M}$ & $3 \mu \mathrm{M}$ & $0.3 \mu \mathrm{M}$ & $1 \mu \mathrm{M}$ & $3 \mu \mathrm{M}$ \\
\hline $\mathrm{E}_{\max }(\%)$ & $36.4 \pm 2.2$ & $50.9 \pm 2.8^{\star}$ & $51.2 \pm 3.0^{\star}$ & $37.2 \pm 2.3$ & $45.0 \pm 2.7$ & $55.7 \pm 4.1^{\star}$ & $36.5 \pm 2.3$ \\
\hline $\mathrm{pEC}_{50}$ value & $7.0 \pm 0.3$ & $6.7 \pm 0.2$ & $6.9 \pm 0.2$ & $6.9 \pm 0.3$ & $6.7 \pm 0.2$ & $6.8 \pm 0.3$ & $7.1 \pm 0.3$ \\
\hline
\end{tabular}

Values are presented as mean \pm standard error of the mean.

DMSO, dimethyl sulfoxide; $\mathrm{E}_{\mathrm{max}}$, maximal effect induced by the agonist; $\mathrm{pEC}_{50}$, negative logarithm of the concentration required for a half-maximal response to an agonist.

${ }^{\star}$ Significantly different from the vehicle (DMSO) group $(\mathrm{P}<0.0001, \mathrm{~F}-$ test $)$. 


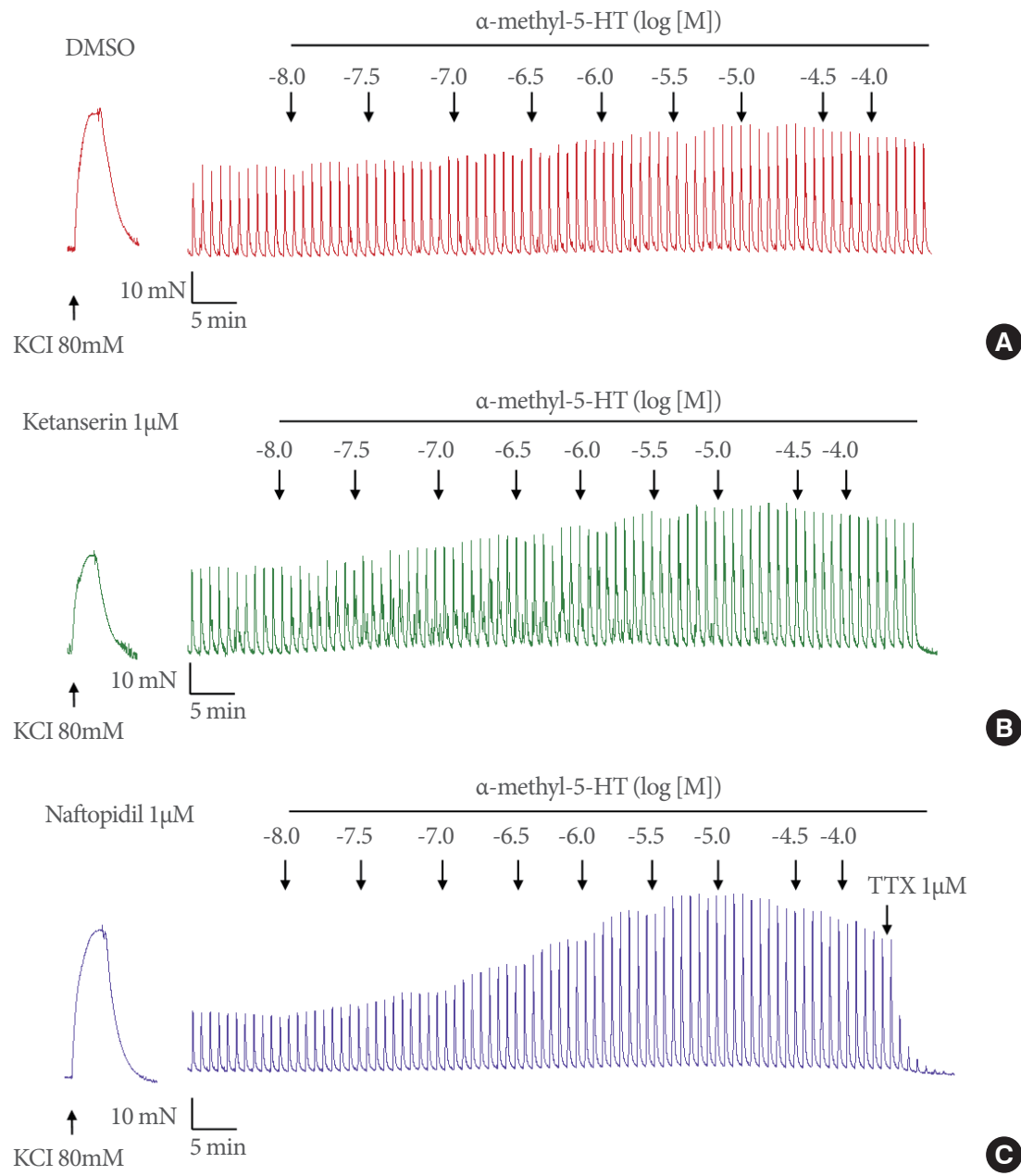

Fig. 2. Representative recording of electrical field stimulation (EFS)-induced contractions in isolated human bladder strips. The potentiating effects of $\alpha$-methyl-5-hydroxytryptamine ( $\alpha$-methyl-5-HT) are shown in panel A. The $\alpha$-methyl-5-HT potentiation was further facilitated in the presence of ketanserin (B) or naftopidil (C). Tetrodotoxin (TTX, 1 $\mu \mathrm{M}$ ) eliminated the reproducible twitch contractions induced by EFS. DMSO, dimethyl sulfoxide.
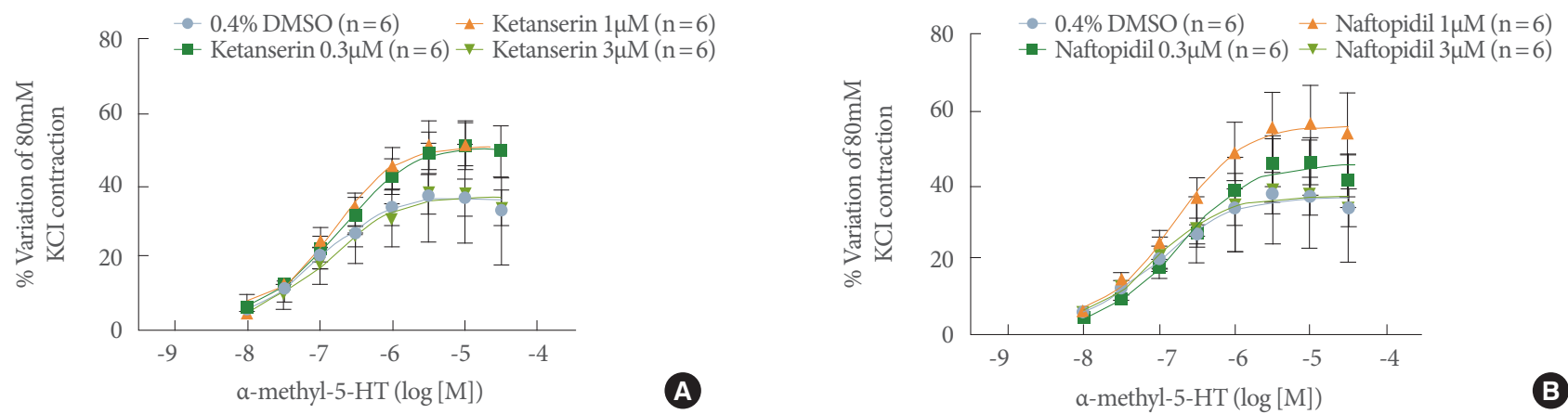

Fig. 3. Effects of ketanserin (A), naftopidil (B), and their common vehicle (0.4\% DMSO) on the a-methyl-5-hydroxytryptamine ( $a$-methyl-5-HT)-induced potentiation of neurogenic contraction in human urinary bladder strips. Contractile responses are expressed as the percentage of the variation of the contraction observed with $80 \mathrm{mM} \mathrm{KCl}$. Data are presented as mean \pm standard error of the mean. Experiments were performed using $\mathrm{n}=6$ strips per group from 4 patients. DMSO, dimethyl sulfoxide. 


\section{DISCUSSION}

This study showed that 5-HT and $\alpha-\mathrm{Me}-5-\mathrm{HT}$ potentiated the EFS-induced contraction of human isolated urinary bladder strips, exerting a similar efficacy, and that ketanserin (0.3 and $1 \mu \mathrm{M})$ and naftopidil $(1 \mu \mathrm{M})$ further enhanced the potentiating effect of $\alpha-\mathrm{Me}-5-\mathrm{HT}$ on detrusor contraction, instead of suppressing the effect. The enhancement was produced by a drug concentration close to that reached in plasma concentration when each drug is given at clinically relevant dose, and these results can therefore be suitably translated into bedside practice $[15,16]$. The contractile responses were mostly neurally mediated, but did not occur owing to direct stimulation of the muscle cells, because the reproducible twitch contractions induced by EFS were eliminated by tetrodotoxin.

The potentiating effect of 5-HT on the EFS-evoked contraction of human isolated bladder strips in this study is comparable to that observed in a previous study by Corsi et al. [6]. Meanwhile, in a study by the same group, $\alpha-\mathrm{Me}-5-\mathrm{HT}$ behaved as a partial agonist relative to 5-HT in the potentiation of EFS-induced contractions, whereas in our study, it exerted the effect of a full agonist. The cause of this discrepancy is unknown, but may be partly attributable to response differences among individuals, differences in $\mathrm{EFS}$ frequency, the reference $\mathrm{KCl}$ concentration, the composition of the Krebs solution, or a combination thereof. We added prazosin to the Krebs solution to isolate the effect of facilitation via $\alpha_{1}$-adrenoceptors on ACh release from the prejunctional parasympathetic nerve terminals and a stimulating effect on postjunctional $\alpha_{1}$-adrenoceptors in the detrusor [17]. Thus, the increased efficacy of $\alpha-\mathrm{Me}-5-\mathrm{HT}$ in the present result in comparison with the previous study [6] is not likely to be due to $\alpha_{1}$-adrenergic mediation.

A recent study using real-time PCR and immunohistochemical techniques revealed that at least $5-\mathrm{HT}_{2 \mathrm{~A}}, 5-\mathrm{HT}_{2 \mathrm{~B}}, 5-\mathrm{HT}_{3 \mathrm{~A}}$, $5-\mathrm{HT}_{4}$, and $5-\mathrm{HT}_{7}$ were expressed in the urothelium, mucosa, and detrusor, and that $5-\mathrm{HT}_{2 \mathrm{~B}}$ receptors were most common in these layers of the bladder [9]. Taken together with the present result showing that the potentiating effect of $\alpha-\mathrm{Me}-5-\mathrm{HT}$ was equivalent to that of 5-HT, it may be presumed that $5-\mathrm{HT}_{2 \mathrm{~B}}$ receptors play a major role in the regulation of urinary bladder function. However, $5-\mathrm{HT}_{2}$ receptor subtypes are not involved in neurally-evoked detrusor contraction because neither ketanserin nor naftopidil suppressed $\alpha-\mathrm{Me}-5-\mathrm{HT}$ potentiation. Similarly, in a previous study [6], ketanserin at a $1 \mu \mathrm{M}$ concentration did not cause a rightward displacement of the CRC for 5-HT (up to $1 \mu \mathrm{M}$ ) in the EFS-induced contraction of human isolated urinary bladder strips.

The contractility or tonus of the detrusor can be locally mediated through multiple complex mechanisms, including a variety of receptors. In the human bladder, the activation of 5- $\mathrm{HT}_{4}$ receptors or $5-\mathrm{HT}_{7}$ receptors in prejunctional parasympathetic nerve terminals facilitates ACh release $[7,8,18]$, thereby potentiating detrusor contraction, whereas the stimulation of 5- $\mathrm{HT}_{1 \mathrm{~A}}$ receptors in cholinergic nerve terminals inhibits its release [8], thereby suppressing contractility. Previously, it has been suggested that $\alpha-\mathrm{Me}-5-\mathrm{HT}$ interacts with 5-HT receptor subtypes other than $5-\mathrm{HT}_{2}$, such as $5-\mathrm{HT}_{1 \mathrm{~A}}$ and most probably $5-\mathrm{HT}_{7}$ [19-21]. Thus, $\alpha-\mathrm{Me}-5-\mathrm{HT}$ potentiation may be activated via $5-\mathrm{HT}_{7}$ receptors, although the inhibitory modulation of ACh release by stimulating $5-\mathrm{HT}_{1 \mathrm{~A}}$ receptors is likely, in part, to simultaneously counteract the potentiation. Moreover, $\alpha-\mathrm{Me}-5-$ HT has been shown to stimulate $\beta_{2}$-receptors [22], which may decrease the detrusor tonus and thus further complicate the interpretation of the present results. It is unknown whether $\alpha-\mathrm{Me}-$ 5-HT interacts with $5-\mathrm{HT}_{4}$ receptors.

In this study, neither ketanserin nor naftopidil at any concentration inhibited the $\alpha-\mathrm{Me}-5$-HT potentiation of EFS-induced contraction of human isolated urinary bladder strips. Instead, each drug at low concentrations enhanced the potentiation of the detrusor contraction; ketanserin at $0.3 \mu \mathrm{M}$ and $1 \mu \mathrm{M}$ and naftopidil at $1 \mu \mathrm{M}$ produced maximal potentiation of contractility. What is the underlying mechanism for the enhancement caused by ketanserin or naftopidil of the potentiating effect of $\alpha-M e-5-$ HT? Ketanserin and naftopidil have $\alpha_{1}$-adrenoceptor antagonism as a common pharmacological property in addition to behaving as $5-\mathrm{HT}_{2}$ antagonists $[23,24]$. Both drugs have been shown to possess a high selectivity for $\alpha_{1 A^{-}}$and $\alpha_{1 D}$-adrenoceptors, with a similar affinity [25-27]. Nevertheless, it is not likely that $\alpha_{1}$ adrenoceptor antagonism, in addition to the prazosin included in Krebs solution, at the prejunctional and postjunctional sites of the detrusor contributed to the enhancement of $\alpha-\mathrm{Me}-5-\mathrm{HT}$ potentiation. Moreover, it is unknown whether ketanserin and naftopidil effectively activate $5-\mathrm{HT}_{4}$ receptors, $5-\mathrm{HT}_{7}$ receptors, or both, which could further enhance the $\mathrm{a}-\mathrm{Me}-5-\mathrm{HT}$ potentiation.

However, ketanserin and naftopidil at the highest concentrations $(3 \mu \mathrm{M})$ completely reversed the enhancement induced by lower concentrations, decreasing it to a level equivalent to the vehicle, Naftopidil has been suggested to possess $5-\mathrm{HT}_{1 \mathrm{~A}}$ agonistic properties [24,28]; thus, it is possible that the drug at $3 \mu \mathrm{M}$ inhibited ACh release by stimulating the inhibitory $5-\mathrm{HT}_{1 \mathrm{~A}}$ 
mechanism in parasympathetic cholinergic terminals, thereby reversing the enhancement. It is unknown whether ketanserin activates the $5-\mathrm{HT}_{1 \mathrm{~A}}$ receptor mechanism. Further studies are necessary to elucidate the complex mechanisms involving these drugs, which exert their effects via multiple receptors.

In the present study, we used bladder tissue samples obtained from patients who had undergone radical cystectomy for bladder cancer, as is common in studies of the human bladder [68,18 ] due to limited availability and ethical reasons. To date, little is known about whether bladder cancer changes the metabolism of 5-HT and the distribution of 5-HT receptor subtypes in the remaining, nontumor part of the bladder; however, increasing evidence has emerged of links between 5-HT and carcinoma [29]. 5-HT exhibits a growth-stimulatory effect and facilitates cell proliferation in aggressive cancers and carcinoids, often through 5- $\mathrm{HT}_{1}$ and $5-\mathrm{HT}_{2}$ receptors [30]. It has been suggested that $5-\mathrm{HT}_{1 \mathrm{~B}}$ antagonists, for example, may be useful in the treatment of bladder cancer [30]. In addition, the progression of some tumors is accompanied by dysregulation of the pattern of 5-HT receptor expression [29]. Serum 5-HT levels have been suggested as suitable prognostic marker to evaluate urological tumors, such as urothelial carcinoma in the urinary bladder, adenocarcinoma of the prostate, and renal cell carcinoma [31]. Thus, the possible influence of bladder cancer on the 5-HT-associated motility response of the detrusor may need to be considered.

Two patients received intravesical BCG therapy before cystectomy. BCG induces the production of proinflammatory cytokines, including interferon- $\gamma$ (IFN $\gamma$ ), tumor necrosis factor- $\alpha$ and interleukin-1 $\beta[32,33]$. Elevation of IFN $\gamma$, which is a dimerized soluble cytokine belonging to the type II class of interferons [32], leads to marked induction of indoleamine 2,3-dioxygenase, a tryptophan-degrading enzyme [34]. This further leads to increased degradation of L-tryptophan via the kynurenine pathway, resulting in decreased 5-HT synthesis [35]. Thus, it is possible that BCG treatment affects the contribution of 5-HT to detrusor motility. In this study, however, BCG-treated bladders showed no difference in the $\alpha-M e-5$-HT CRC of detrusor contraction compared to what was observed in nonBCG bladders, suggesting that the 4-month interval between the last treatment and cystectomy (and the experiment) was long enough for the functional contribution of 5-HT to be restored in the bladder.

In conclusion, $5-\mathrm{HT}_{2}$ receptors in the human urinary bladder were not found to participate in the neural modulation of detru- sor motor function. It is possible that $5-\mathrm{HT}_{2}$ receptors are involved in bladder sensory transmission in the afferent pathway, in addition to nonneural detrusor motility. Meanwhile, our results regarding ketanserin and naftopidil were favorable, because these drugs led to enhanced detrusor contraction. Ketanserin has been reported to increase the maximum and mean urine flow rates and to decrease urethral pressure in male patients with prostatism [13]. Naftopidil has been clinically used to treat patients with prostatic hypertrophy and has been also reported to increase the maximum urine flow rate and decrease pressure at the maximum urinary flow rate [14]. Overall, our results suggest the possibility that ketanserin and naftopidil, both of which enhance detrusor contractility and reduce urethral resistance, may be useful for treating prostatism/bladder outlet obstruction, especially concurrent with detrusor hypomotility, as manifested in conditions such as underactive bladder.

\section{ACKNOWLEDGEMENTS}

The authors thank Dr. Matthieu Thoulouzan and Dr. Mathieu Roumiguié for their careful work in the surgical excision and processing of the urinary bladders.

\section{REFERENCES}

1. Hannon J, Hoyer D. Molecular biology of 5-HT receptors. Behav Brain Res 2008;195:198-213.

2. Alexander SP, Davenport AP, Kelly E, Marrion N, Peters JA, Benson HE, et al. The Concise Guide to PHARMACOLOGY 2015/16: G protein-coupled receptors. Br J Pharmacol 2015;172:5744-869.

3. Anderson KE. Pharmacology of lower urinary tract smooth muscles and penile erectile tissues. Pharmacol Rev 1993;45:253-308.

4. Ramage AG. The role of central 5-hydroxytryptamine (5-HT, serotonin) receptors in the control of micturition. Br J Pharmacol 2006; 147 Suppl 2:S120-31.

5. Klarskov P, Hørby-Petersen J. Influence of serotonin on lower urinary tract smooth muscle in vitro. Br J Urol 1986;58:507-13.

6. Corsi M, Pietra C, Toson G, Trist D, Tuccitto G, Artibani W. Pharmacological analysis of 5-hydroxytryptamine effects on electrically stimulated human isolated urinary bladder. Br J Pharmacol 1991;104:71925.

7. Candura SM, Messori E, Franceschetti GP, D’Agostino G, Vicini D, Tagliani M, et al. Neural 5-HT4 receptors in the human isolated detrusor muscle: effects of indole, benzimidazolone and substituted benzamide agonists and antagonists. Br J Pharmacol 1996;118:1965-70. 
8. D’Agostino G, Condino AM, Gallinari P, Franceschetti GP, Tonini M. Characterization of prejunctional serotonin receptors modulating $[3 \mathrm{H}]$ acetylcholine release in the human detrusor. J Pharmacol Exp Ther 2006;316:129-35.

9. Imamura T, Ishizuka O, Ogawa T, Minagawa T, Ishikawa M, Hiragata $\mathrm{S}$, et al. Expression of 5-hydroxytryptamine receptors in human urinary bladders with benign prostatic hyperplasia. Adv Ther 2015;32 Suppl 1:29-37.

10. Baxter G, Kennett G, Blaney F, Blackburn T. 5-HT2 receptor subtypes: a family re-united? Trends Pharmacol Sci 1995;16:105-10.

11. Ismaiel AM, Arruda K, Teitler M, Glennon RA. Ketanserin analogues: the effect of structural modification on 5-HT2 serotonin receptor binding. J Med Chem 1995;38:1196-202.

12. Sakai T, Kasahara K, Tomita K, Ikegaki I, Kuriyama H. Naftopidil inhibits 5-hydroxytryptamine-induced bladder contraction in rats. Eur J Pharmacol 2013;700:194-200.

13. Hørby-Petersen J, Schmidt PF, Meyhoff HH, Frimodt-Møller C, Mathiesen FR. The effects of a new serotonin receptor antagonist (ketanserin) on lower urinary tract function in patients with prostatism. J Urol 1985;133:1094-8.

14. Gotoh M, Kamihira O, Kinukawa T, Ono Y, Ohshima S, Origasa H, et al. Comparison of tamsulosin and naftopidil for efficacy and safety in the treatment of benign prostatic hyperplasia: a randomized controlled trial. BJU Int 2005;96:581-6.

15. Farthing MJ, Alstead EM, Abrams SM, Haug G, Johnston A, Hermann R, et al. Pharmacokinetics of naftopidil, a novel anti-hypertensive drug, in patients with hepatic dysfunction. Postgrad Med J 1994;70:363-6.

16. Reimann IW, Okonkwo PO, Klotz U. Pharmacokinetics of ketanserin in man. Eur J Clin Pharmacol 1983;25:73-6.

17. de Groat WC, Yoshiyama M, Ramage AG, Yamamoto T, Somogyi GT. Modulation of voiding and storage reflexes by activation of alpha1-adrenoceptors. Eur Urol 1999;36 Suppl 1:68-73.

18. Tonini M, Messori E, Franceschetti GP, Rizzi CA, Castoldi AF, Coccini T, et al. Characterization of the 5-HT receptor potentiating neuromuscular cholinergic transmission in strips of human isolated detrusor muscle. Br J Pharmacol 1994;113:1-2.

19. Ismaiel AM, Titeler M, Miller KJ, Smith TS, Glennon RA. 5-HT1 and 5-HT2 binding profiles of the serotonergic agents alpha-methylserotonin and 2-methylserotonin. J Med Chem 1990;33:755-8.

20. Feldman PD. Effects of serotonin-1 and serotonin-2 receptor agonists on neuronal activity in the nucleus tractus solitarius. J Auton Nerv Syst 1995;56:119-24.

21. Hoyer D, Clarke DE, Fozard JR, Hartig PR, Martin GR, Mylecharane EJ, et al. International Union of Pharmacology classifica- tion of receptors for 5-hydroxytryptamine (Serotonin). Pharmacol Rev 1994;46:157-203.

22. Campos-Bedolla P, Vargas MH, Calixto E, Segura P, MendozaPatiño N, Figueroa A, et al. Alpha-methyl-5-HT, a 5-HT2 receptor agonist, stimulates beta2-adrenoceptors in guinea pig airway smooth muscle. Pharmacol Res 2006;54:468-73.

23. Hoyer D, Vos P, Closse A, Pazos A, Palacios JM, Davies H. [3H] ketanserin labels 5-HT2 receptors and alpha 1-adrenoceptors in human and pig brain membranes. Naunyn Schmiedebergs Arch Pharmacol 1987;335:226-30.

24. Sorbi C, Franchini S, Tait A, Prandi A, Gallesi R, Angeli P, et al. 1,3-Dioxolane-based ligands as rigid analogues of naftopidil: structure-affinity/activity relationships at alphal and 5-HT1A receptors. ChemMedChem 2009;4:393-9.

25. Israilova M, Suzuki F, Tanaka T, Nagatomo T, Taniguchi T, Muramatsu I. Binding and functional affinity of sarpogrelate, its metabolite $\mathrm{m}-1$ and ketanserin for human recombinant alpha-1-adrenoceptor subtypes. Pharmacology 2002;65:69-73.

26. Sathi ZS, Anisuzzaman AS, Morishima S, Suzuki F, Tanaka T, Yoshiki $\mathrm{H}$, et al. Different affinities of native alpha1B-adrenoceptors for ketanserin between intact tissue segments and membrane preparations. Eur J Pharmacol 2008;584:222-8.

27. Takei R, Ikegaki I, Shibata K, Tsujimoto G, Asano T. Naftopidil, a novel alpha1-adrenoceptor antagonist, displays selective inhibition of canine prostatic pressure and high affinity binding to cloned human alphal-adrenoceptors. Jpn J Pharmacol 1999;79:447-54.

28. Borbe HO, Metzenauer P, Szelenyi I. 5-HT1A-agonistic properties of naftopidil, a novel antihypertensive drug. Eur J Pharmacol 1991; 205:105-7.

29. Sarrouilhe D, Clarhaut J, Defamie N, Mesnil M. Serotonin and cancer: what is the link? Curr Mol Med 2015;15:62-77.

30. Siddiqui EJ, Shabbir MA, Mikhailidis DP, Mumtaz FH, Thompson CS. The effect of serotonin and serotonin antagonists on bladder cancer cell proliferation. BJU Int 2006;97:634-9.

31. Jungwirth N, Haeberle L, Schrott KM, Wullich B, Krause FS. Serotonin used as prognostic marker of urological tumors. World J Urol 2008;26:499-504.

32. Moreau M, Lestage J, Verrier D, Mormede C, Kelley KW, Dantzer $\mathrm{R}$, et al. Bacille Calmette-Guérin inoculation induces chronic activation of peripheral and brain indoleamine 2,3-dioxygenase in mice. J Infect Dis 2005;192:537-44.

33. Moreau M, André C, O’Connor JC, Dumich SA, Woods JA, Kelley $\mathrm{KW}$, et al. Inoculation of Bacillus Calmette-Guerin to mice induces an acute episode of sickness behavior followed by chronic depressive-like behavior. Brain Behav Immun 2008;22:1087-95. 
34. Maes M, Leonard BE, Myint AM, Kubera M, Verkerk R. The new '5-HT' hypothesis of depression: cell-mediated immune activation induces indoleamine 2,3-dioxygenase, which leads to lower plasma tryptophan and an increased synthesis of detrimental tryptophan catabolites (TRYCATs), both of which contribute to the onset of depression. Prog Neuropsychopharmacol Biol Psychiatry 2011;
$35: 702-21$.

35. O'Connor JC, Lawson MA, André C, Moreau M, Lestage J, Castanon N, et al. Lipopolysaccharide-induced depressive-like behavior is mediated by indoleamine 2,3-dioxygenase activation in mice. Mol Psychiatry 2009;14:511-22. 